\title{
KONTRIBUSI PENGGUNAAN SEMPOA DALAM MATAKULIAH ARITMATIKA TERHADAP KEMAMPUAN BERPIKIR KREATIF MATEMATIS
}

\author{
Anwar Ardani ${ }^{1)}$, Dian Purwaningsih ${ }^{2)}$ \\ 1) Universitas Peradaban, anwarardani3@gmail.com \\ ${ }^{2)}$ Universitas Peradaban, dian.purwaningsih24@yahoo.com
}

\begin{abstract}
Abstrak
Tujuan penelitian ini yaitu: a) untuk mengetahui hubungan penggunaan sempoa dalam matakuliah aritmatika terhadap kemampuan berpikir kreatif matematis, b) untuk mengetahui pengaruh penggunaan sempoa dalam mata kuliah aritmatika terhadap kemampuan berpikir kreatif matematis. Jenis penelitian ini adalah penelitian eksplanasi (explanation) dengan pendekatan kuantitatif. Dalam penelitian ini dilakukan uji analisis korelasi untuk mengetahui hubungan pengunaan sempoa terhadap kemampuan berpikir kreatif matematis, dan uji analisis regresi sederhana untuk mengetahui pengaruh penggunaan sempoa terhadap kemampuan berpikir kreatif matematis. Uji analisis ini menggunakan SPPS. Berdasarkan hasil analisis terdapat koefisien korelasi penggunaan sempoa terhadap kemampuan berpikir kreatif matematis bernilai positif sebesar 0,808. Penggunaan sempoa memberikan pengaruh sebesar $65,2 \%$ terhadap kemampuan berbikir kreatif matematis.
\end{abstract}

Kata Kunci: Sempoa, aktivitas, kemampuan berpikir kreatif matematis

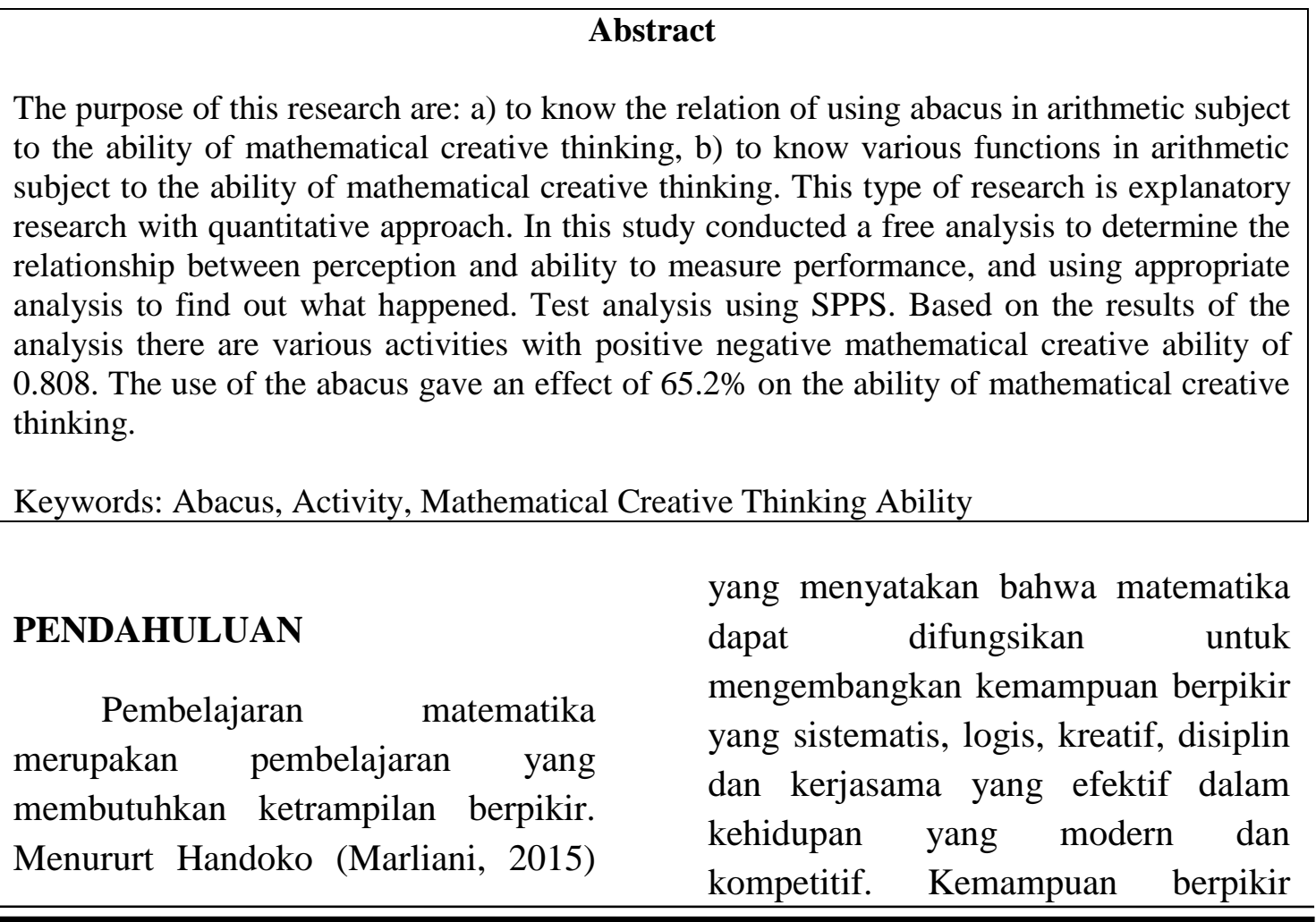


menurut De Bono (Marliani, 2015) mendefinisikan berpikir sebagai ketrampilan mental yang memadukan kecerdasan dengan pengalaman.

Kemampuan berpikir dalam pembelajaran matematika salah satunya yaitu berpikir kreatif. Bishop (Pehnoken, 1997) menyatakan bahwa seseorang memerlukan dua ketrampilan berpikir matematis, yaitu berpikir kreatif dan berpikir analitik (berpikir logis). Berpikir kreatif merupakan kemampuan berpikir tingkat tinggi. Siswono (2005) menyatakan bahwa berpikir kreatif merupakan suatu proses yang digunakan ketika mendatangkan/memunculkan suatu ide baru. Hal ini mahasiswa dapat memunculkan dan menemukan ide-ide baru dalam menyelesaikan suatu masalah. Menurut Munandar (2012) terdapat empat kajian kreatif dalam matematika yaitu kelancaran (fluency), keluwesan (fleksibilitas), keaslian (orisiniitas) dan terperinci (elaborasi).

Berdasarkan observasi rendahnya kemampuan berpikir kreatif mahasiswa didukung oleh pembiasaan yang dilakukan dalam proses pembelajaran yang dilakukan secara monoton sehingga membuat motivasi mahasiswa dalam pembelajaran menurun serta pembelajaran terasa membosankan. Berdasarkan hal tersebut salahsatu solusinya dengan cara pengajaran yang membuat mahasiswa lebih berpikir kreatif dengan memberikan kontribusi yang menarik dalam pembelajaran. Cara pengajaran yang dapat menarik perhatian siswa yaitu dengan penggunaan alat peraga atau media pembelajaran matematika. Kegunaan media menurut Sudjana dan Rifai (Ngatyo, 2012) yaitu: pembelajaran akan lebih menarik perhatian peserta didik sehingga dapat menumbuhkan motivasi belajar, (2) bahan pembelajaran akan lebih jelas maknanya, (3) metode mengajar akan lebih bervariasi, (4) peserta didik akan lebih banyak melakukan kegiatan belajar.

Media pembelajaran yang dapat digunakan dalam menumbuhkan motivasi dan aktivitas mahasiswa salahsatunya sempoa. Sempoa merupakan alat peraga yang digunakan dalam pembelajaran mata kuliah aritmatika. Sedangkan aritmatika merupakan mata kuliah jurusan Pendidikan Sekolah Dasar (PGSD). Sempoa dapat digunakan dalam operasi aritmatika seperti penjumlahan, pengurangan, perkalian dan pembagian. Tujuan penelitian ini yaitu: a) untuk mengetahui hubungan penggunaan sempoa dalam matakuliah aritmatika terhadap kemampuan berpikir kreatif matematis, b) untuk mengetahui pengaruh penggunaan sempoa dalam mata kuliah aritmatika terhadap kemampuan berpikir kreatif matematis.

\section{LANDASAN TEORI \\ Sempoa}

Menurut Suhartanti

(2004) penggunaan teknik sempoa adalah suatu cara untuk membantu, mempermudah, bukan mempersulit anak untuk mempelajari matematika 
secara aktif baik otak, peradaba, serta ketajaman penglihatan, sehingga anak tidak menjadi jenuh. Menurut Prasetyono (2009) menjelaskan bahwa dekak-dekak (sempoa) merupakan alat yang terbuat dari kayu dan manikmanik yang bisa digeser. Sempoa dapat digunakan untuk melakukan operasi aritmatika seperti penjumlahan, pengurangan, perkalian dan pembagian.

\section{Aktivitas}

$\begin{array}{ccr}\text { Menurut } & \text { Hamalik (2010) } \\ \text { mengemukakan } & \text { bahwa aktivitas }\end{array}$ merupakan segala kegiatan yang dilakukan dalam proses interaksi dalam rangka mencapai tujuan belajar. Sedangkan menurut Sardiman (2004) menjelaskan bahwa aktivitas belajar adalah kegiatan-kegiatan siswa yang menunjang keberhasilan belajar. Klasifikasi aktivitas belajar ada delapan kelompok seperti yang dijelaskan Dierich ( Hamalik, 2010) yaitu:

a. Visual Activities, meliputi: (1) memperhatikan penjelasan guru, (2) memperhatikan pekerjaan orang lain dalam kelompoknya, (3) memperhatikan presentasi kelompok lain.

b. Oral Activities, meliputi: (1) keaktifan dalam mengajukan pertanyaan, (2) keaktifan dalam menjawab pertanyaan, (3) mampu mengemukakan pendapat atau merespon pertanyaan dalam diskusi kelompok.

c. Listening Activities, meliputi: (1) mampu mendengarkan penjelasan / percakapan dalam diskusi dikelompoknya, (2) mampu mendengarkan penjelasan / presentasi dari kelompok lain.

d. Writing Activities, meliputi: (1) keaktifan menyelesaikan tugas dalam kelompok, (2) membuat catatan pentin/menulis penjelasan guru dan hasil diskusi, (3) mampu membuat kesimpulan hasil diskusi.

e. Drawing Activities, meliputi: mampu membuat gambar/ilustrasi guna menyelesaikan pemecahan masalah matematika sesuai permasalahan soal

f. Motor Activities, meliputi: (1) aktif mengikuti jalannya pembelajaran, (2) aktif melaksanakan tugas rumah, (3) aktif mengikuti jalannya diskusi, (4) mampu mengembangkan berpikir kritis dan kreatif dalam diskusi.

g. Emosional Activities, meliputi: (1) bersemangat dan menaruh minat dalam kegiatan pembelajaran, (2) bersikap tenang dalam pembelajaran.

\section{Berpikir Kreatif Matematis}

Menurut Pehkonen

(1997) mendefinisikan berpikir kreatif sebagai kombinasi antara berpikir logis dan berpikir divergen yang didasarkan pada intuisi tapi dalam kesadaran. Guilford (Kiswandono, 2000) yang mengatakan bahwa berpikir kreatif, sebagai kemampuan untuk melihat bermacam-macam kemungkinan penyelesaian terhadap suatu masalah, merupakan bentuk pemikiran yang sampai saat ini masih kurang mendapatkan perhatian dalam pendidikan formal. Menurut Evans (Alimudin, 2009) menjelaskan bahwa berpikir kreatif adalah suatu aktivitas 
mental untuk membuat hubunganhubungan (conections) yang terus menerus (kontinu), sehingga ditemukan kombinasi yang "benar" atau sampai seseorang itu menyerah. Siswono (2005) menyatakan bahwa berpikir kreatif merupakan suatu proses yang digunakan ketika mendatangkan/memunculkan suatu ide baru.

Menurut Munandar indikator kemampuan berpikir kreatif yaitu: (1) kefasihan, (2) keluwesan, (3) kebaruan, (4) keterincian.

1. Kefasihan/kelancaran (Fluency) Aspek kelancaran meliputi kemampuan: (1) menyelesaikan masalah dan memberikan banyak jawaban terhadap masalah tersebut; atau (2) memberikan banyak contoh atau pernyataan terkait konsep atau situasi matematis tertentu.

2. Keluwesan (Flexibility)

Aspek keluwesan meliputi kemampuan: (1) menggunakan beragam strategi penyelesaian masalah; atau (2) memberikan beragam contoh atau pernyataan terkait konsep atau situasi matematis tertentu.

3. Kebaruan (Originality)

Aspek kebaruan meliputi kemampuan: (1) menggunakan strategi yang bersifat baru, unik, atau tidak biasa untuk menyelesaikan masalah; atau (2) memberikan contoh atau pernyataan yang bersifat baru, unik, atau tidak biasa.

4. Keterincian (Elaboration) Aspek keterincian meliputi kemampuan menjelaskan secara terperinci, runtut, dan koheren terhadap prosedur matematis, jawaban, atau situasi matematis tertentu.

\section{METODE PENELITIAN}

Jenis penelitian ini adalah penelitian eksplanasi (explanation) yaitu penelitian yang menjelaskan kedudukan variable-variabel yang diteliti serta hubungan antara satu variabel dengan variabel yang lain (Sugiyono, 2011). Pendekatan penelitian ini adalah pendekatan kuantitatif. Penelitian ini dilaksanakan di Universitas Peradaban tahun ajaran 2016/2017. Populasi penelitian ini adalah mahasiswa jurusan Pendidikan Guru Sekolah Dasar (PGSD) Universitas Peradaban semester VI Tahun Akademik 2016/2017 yang berjumlah 4 kelas. Sedangkan sampel penelitian ini yaitu mahasiswa PGSD 2.

Variabel penelitian ini yaitu variabel independen (variable bebas) dalam penelitian ini yaitu penggunaan sempoa. Penggunaan sempoa dilihat dari aktivitas mahasiswa. Variabel dependen (variable terikat) dalam penelitian ini yaitu kemampuan berpikir kreatif matematis. Instrumen penelitian yang digunakan yaitu lembar observasi dan lembar angket.

Pengumpulan data dilakukan dengan metode angket, metode observasi, dan metode dokumentasi. Metode observasi dilakukan untuk melihat aktivitas mahasiswa dalam penggunaan sempoa. Metode angket dilakukan untuk mendapatkan hasil kemampuan berpikir kreatif matematis 
mahasiswa. Analisis data yang digunakan dalam penelitian ini yaitu uji analisis korelasi dan analisis regresi sederhana.

\section{PEMBAHASAN}

Dalam penelitian ini dilakukan uji analisis korelasi untuk mengetahui hubungan pengunaan sempoa terhadap kemampuan berpikir kreatif matematis, dan uji analisis regresi sederhana untuk mengetahui pengaruh penggunaan sempoa terhadap kemampuan berpikir kreatif matematis. Uji analisis ini menggunakan SPPS.

\section{Untuk mengetahui hubungan penggunaan sempoa terhadap kemampuan berpikir kreatif matematis sebagai berikut.}

Hasil uji korelasi penggunaan sempoa terhadap kemampuan berpikir kreatif matematis dapat dilihat pada table 1 berikut.

\section{Tabel 1. Correlations}

\begin{tabular}{llrr}
\hline & & Aktivitas & \multicolumn{2}{c}{$\begin{array}{c}\text { Berpikir } \\
\text { kreatif }\end{array}$} \\
\hline Aktivitas & Pearson Correlation & 1 & $.808^{\star *}$ \\
& Sig. (2-tailed) & & .000 \\
& $\mathrm{~N}$ & 38 & 38 \\
\hline Berpikir kreatif & Pearson Correlation & $.808^{\star \pi}$ & 1 \\
& Sig. (2-tailed) & .000 & \\
& $\mathrm{~N}$ & 38 & 38 \\
\hline
\end{tabular}

Berdasarkan tabel diatas terlihat bahwa koefisien korelasi penggunaan sempoa terhadap kemampuan berpikir kreatif matematis bernilai positif sebesar 0,808 sehingga tingkat korelasinya termasuk dalam kategori tinggi. Sedangkan nilai signifikan sebesar $0,000<0,05$ maka $\mathrm{H}_{0}$ ditolak sehingga terdapat korelasi yang signifikan penggunaan sempoa terhadap kemampuan berpikir kreatif matematis.
Untuk mengetahui pengaruh penggunaan sempoa terhadap kemampuan berpikir kreatif matematis sebagai berikut.

Untuk menganalisis pengaruh penggunaan sempoa terhadap kemampuan berpikir kreatif matematis digunakan regresi sederhana dan diperoleh hasil yang dapat dilihat pada Tabel 2. berikut

\begin{tabular}{lrrrrr}
\multicolumn{6}{c}{ Tabel 2. ANOVA } \\
\hline Model & Sum of & & \multicolumn{1}{l}{ Mean } & & \\
\hline 1 Regression & Squares & Df & Square & F & Sig. \\
$\quad$ Residual & 1335.348 & 1 & 1335.348 & 67.573 & $.000^{\mathbf{a}}$ \\
Total & 711.415 & 36 & 19.762 & & \\
\hline
\end{tabular}


Dari hasil olah data di atas diperoleh nilai $F=67,573$ dengan sig $0,000<$ 0,05 yang berarti $\mathrm{H}_{0}$ ditolak, artinya persamaan regresi sederhana bahwa penggunaan sempoa berpengaruh terhadap kemampuan berpikir kreatif matematis.
Untuk mengukur besarnya pengaruh penggunaan sempoa terhadap kemampuan berpikir kreatif matematis dapat dilihat dari Tabel 3 berikut

Tabel 3. Model Summary

\begin{tabular}{lrrrr}
\hline Model & $\mathrm{R}$ & R Square & $\begin{array}{c}\text { Adjusted R } \\
\text { Square }\end{array}$ & \multicolumn{2}{c}{$\begin{array}{c}\text { Std. Error of the } \\
\text { Estimate }\end{array}$} \\
\hline 1 & $.808^{\mathrm{a}}$ & .652 & .643 & 4.445 \\
\hline
\end{tabular}

Besarnya pengaruh dapat dilihat dari nilai $\mathrm{R}$ Square $=0,652=65,2 \%$ yang berarti $65,2 \%$ kemampuan berpikir kreatif matematis dipengaruhi oleh penggunaan sempoa dan sisanya $34,8 \%$ dipengaruhi oleh faktor lain.

\begin{abstract}
Kemudian untuk mengetahui bentuk persamaan regresinya penggunaan sempoa terhadap kemampuan berpikir kreatif matematis dapat dilihat dari Tabel 4 berikut.
\end{abstract}

Tabel 4. Coefficients ${ }^{\mathrm{a}}$

\begin{tabular}{|c|c|c|c|c|c|}
\hline \multirow[b]{2}{*}{ Model } & \multicolumn{2}{|c|}{$\begin{array}{l}\text { Unstandardized } \\
\text { Coefficients }\end{array}$} & \multirow{2}{*}{$\begin{array}{c}\text { Standardized } \\
\text { Coefficients }\end{array}$} & \multirow[b]{2}{*}{$\mathrm{T}$} & \multirow[b]{2}{*}{ Sig. } \\
\hline & $\mathrm{B}$ & Std. Error & & & \\
\hline 1 (Constant) & -3.706 & 9.592 & & -.386 & .702 \\
\hline Aktivitas & .922 & .112 & .808 & 8.220 & .000 \\
\hline
\end{tabular}

Dari Tabel 4 di atas dapat dilihat hubungan penggunaan sempoa terhadap kemampuan berpikir kreatif matematis yang ditunjukkan pada persamaan regresi. Bentuk persamaan regresinya yaitu $\hat{Y}=-3,706+0,922 x$ artinya setiap penambahan variabel penggunaan sempoa sebesar satu satuan maka akan menambah nilai kemampuan berpikir kreatif matematis sebesar 0,922, maka $\mathrm{H}_{0}$ ditolak dan terima $\mathrm{H}_{1}$ artinya penggunaan sempoa berpengaruh terhadap kemampuan berpikir kreatif matematis. Persamaan regresi tersebut dapat dijadikan sebagai dasar memprediksi kemampuan berpikir kreatif matematis mahasiswa jika diketahui nilai aktivitas mahasiswa pada penggunaan sempoa tersebut.

\section{KESIMPULAN DAN SARAN Kesimpulan}

Berdasarkan rumusan masalah, tujuan, hipotesis dan pembahasan, maka dapat disimpulkan sebagai berikut.

1. Ada hubungan positif anatara penggunaan sempoa dalam matakuliah aritmatika terhadap kemampuan berpikir kreatif matematis

2. Terdapat pengaruh positif penggunaan sempoa dalam mata kuliah aritmatika terhadap kemampuan berpikir kreatif matematis.

\section{Saran}

Sempoa dalam pembelajaran matematika terutama dalam materi aritmatika dapat dijadikan alternatif untuk meningkatkan kemampuan berpikir kreatif siswa. Penggunaan 
sempoa juga bisa digunakan dalam pembelajaran matematika baik di jenjang dasar maupun menengah.

\section{DAFTAR PUSTAKA}

Alimuddin. (2009). Menumbuh Kembangkan Kemampuan Berpikir Kreatif Siswa Melalui Tugas-Tugas Pemecahan Masalah. Tersedia di: http://eprits.uny.ac.id/12261/1/M Pend 5 Alimuddin.pdf

Hamalik, O. (2010). Proses Belajar Mengajar. Jakarta: Bumi Aksara.

Kiswandono, I. (2000). Berpikir Kreatif Suatu Pendekatan Menuju Berpikir Arsitektual. Universitas Kristen Petra.

Marliani, N. (2015). Peningkatan kemampuan berpikir Kreatif Matematis Siswa Melalui Model Pembelajaran Missouri Mathematics Project (MMP). Tersedia di: http://journal.lppmunindra.ac.id/ index.php/Formatif/article/down $\underline{\text { load/166/159 }}$

Munandar, U. Mengembangkan Bakat dan Kreativitas Anak Sekolah. Jakarta: Gransindo.
Ngatyo, dkk. (2012). Peningkatan aktivitas Belajar Siswa Menggunakan Media Kartu Bilangan Pada Pembelajaran Matematika. Tersedia di: http://jurnal.untan.ac.id/index.p hp/jpdpb/article/viewFile/831/p $\underline{\text { df }}$

Pehkonen, E. (1997). The State-of-Art in Mathematical Creativity, ZDM International Reviews on Mathematical Education. Tersedia di: https://www.emis.de/journals/Z DM/zdm973a1.pdf

Sardiman. (2004). Interaksi dan Motivasi Belajar Mengajar. Jakarta: Raja Grafindo Persada.

Siswono, E. (2005). "Upaya Meningkatkan Kemampuan Berpikir Kreatif Siswa Melalui Pengajuan Masalah". Jurnal Pendidikan Matematika dan Sains. Tahun X, No. 1, Juni 2005. ISSN 1410-1866, hal 1-9.

Sugiyono. (2011). Metode Penelitian Kuantitatif, Kualitatif, dan $R \& D$. Bandung: Alfabeta.

Sukestiyarno. (2010). Olah Data Penelitian Berbantuan SPSS. Universitas Negeri Semarang. 